\title{
Positive Management of Universities: A Model of Motivation to Strive for Scientific Excellence
}

\author{
Beata A. Basińska, Krzysztof Leja, Magdalena Szuflita-Żurawska
}

\section{A B S T R A C T}

Objective: The aim of the article is to conceptualise a model of work motivation in the management of universities striving for scientific excellence.

Research Design \& Methods: The most relevant for our aim is the self-determination theory that is applied to the work and organisational domain. We used a narrative literature review.

Findings: The proposed model is derived from the self-determination theory. It includes three types of motivation: autonomous motivation, controlled motivation, and amotivation, as well as three psychological needs, i.e. autonomy, mastery, and purpose. These motives and needs can interact to enhance scientific effectiveness further.

Implications \& Recommendations: Universities need innovative staff who can contribute to strengthening scientific productivity and enhance the influence of the university at the international level.

Contribution \& Value Added: Connection of three perspectives - institutional, individual and scientific disciplines - will capture the complexities of managing work motivation oriented to scientific effectiveness.

\begin{tabular}{|c|c|}
\hline Article type: & $\begin{array}{l}\text { research article } \\
\text { motivation; university management; scientific effectiveness; psy- } \\
\text { chological needs; positive organisational scholarship; self-determi- } \\
\text { nation theory }\end{array}$ \\
\hline JEL codes: & 123 \\
\hline Received: 13 & Accepted: 21 June 2019 \\
\hline
\end{tabular}

Suggested citation:

Basińska, B.A., Leja, K., \& Szuflita-Żurawska, M. (2019). Positive Management of Universities: A Model of Motivation to Strive for Scientific Excellence. Entrepreneurial Business and Economics Review, 7(3), 237-250. https://doi.org/10.15678/EBER.2019.070313 


\section{INTRODUCTION}

The second mission of universities is to strive for scientific excellence (Scott, 2006), as expressed in the academic community, by publishing in highly ranked peer-reviewed journals, peer-reviewing scientific articles, collaborating with other scientists and receiving funding grants (Kwiek, 2018). The development of an organisation is affected by the configuration of its institutional resources, the exploration and implementation of ways of strengthening it and the identification of strengths and opportunities (Cameron et al., 2003; Cameron \& Spreitzer, 2011). That is why universities need proactive staff who, through their scientific activities, practices and cooperation, will build up prestige and recognition at the international level. However, scientific effectiveness depends not only on the skills of individual academics but also on an appropriate system of motivation. Recent changes in the landscape of scholarly communication have shown that motivation based on external instruments in the form of rewards and punishments is insufficient and poorly matched to the goals of universities (Cerasoli, Nicklin, \& Ford, 2014; Leja, 2015). Furthermore, very few studies into motivation among academics have focused on the institutional and the individual lenses (Blind, Pohlisch, \& Zi, 2018; Christensen, Dyrstad, \& Innstrand, 2018; Teye et al., 2019). Thus, a more appropriate model of motivation in academics is needed. Our study will fill a gap in the areas of the higher education research and management science.

The aim of this study is to conceptualise a model of motivation of academics in the management of universities. As its theoretical framework, it will use a combination of the management paradigm with its strategic paradoxes (antinomy of synergy; Leja, 2013) and positive organisational scholarship (Cameron et. al., 2003; Cameron \& Spreitzer, 2011). Our study concerns a model of work motivation in line with the assumptions of the selfdetermination theory in work organisations (Deci, Olafsen, \& Ryan, 2017; Pink, 2009). The model of motivation includes the following: autonomous motivation (e.g., intrinsic motivation), controlled motivation (e.g., extrinsic motivation) and amotivation (lack of motivation), integrated with psychological needs of autonomy, mastery and purpose. In particular, we would like to highlight that motivation can be treated as a mediator between institutional resources and scientific effectiveness.

In the article the considerations are carried out in accordance with the worldview of social constructivism, typical in the case of qualitative research. The logic of the argument is based on the synthesis of paradigms of positive organisational scholarship (Cameron et. al., 2003; Cameron \& Spreitzer, 2011) and the management of paradoxes (Leja, 2013; Lewis, 2000). Therefore, a narrative literature review is applied as a research method. It provides critical evaluation of previous studies and synthesis of the review of literature on work motivation, in line with the self-determination theory (Deci, Olafsen, \& Ryan, 2017).

The article is divided into four main parts. The first part (Literature Review) illustrates the scientific effectiveness and scientific productivity including the Polish scientific context. The second part (Material and Method) describes the research methods and the methodology approach used. The third part (Theory Development) presents the conceptualisation of a model of work motivation among scientists based on the selfdetermination theory adopted in the work domain. The fourth part (Conclusion) summarises and discusses practical implications and further recommendation for positive management of universities. 


\section{LITERATURE REVIEW}

\section{Management of Universities}

A necessary condition for the creation of new knowledge is the ability to synthesise opposites and manage paradoxes in organisations (Lewis, 2000; Smith \& Lewis, 2011). In university management, the synergy of antinomy is needed. This requires to integrate conflicting requirements and conditions that result in tensions (Leja, 2013; Tabatoni, 2002). The major strategic tensions in the higher education system are the level of education excellence (quality versus mass), the outcomes of education (general academic skills versus skills determined by the needs of the labour market) and research funding (autonomy of academics versus social needs). It is therefore essential to understand the paradoxes (Cohen, 1998) and to use them as an asset belonging to the entire organisation (Lewis, 2000). Managing an organisation's strategy can be viewed as a long-term plan for exploiting opportunities that can be a significant source of competitive advantage in the future (Krupski, Niemczyk, \& Stańczyk-Hugiet, 2009).

Focusing on the positive aspects and advantages is a crucial element of the paradigm of Positive Organisational Scholarship. The development of an organisation is affected by the configuration of its institutional resources, the exploration and implementation of ways of strengthening it and the identification of strengths and opportunities (Cameron et al., 2003; Cameron \& Spreitzer, 2011). In these ways, it is possible to enhance the institution's contribution to the growth and thriving of its employees and to scientific effectiveness in the higher education system.

\section{Academic Productivity}

Work motivation is one of the key factors determining the effectiveness of work performance. Scientific effectiveness in the higher education system is defined as publishing and reviewing in international journals, applying for research grants and external funding, as well as collaborating in scientific teams (Kwiek, 2018). This definition of scientific effectiveness is relatively new to the Polish higher education system and stems from significant changes that occurred after 2011, when it was assumed that scientific effectiveness would be primarily related to the presence and recognition of Polish academics at the international level. A similar strategy of internationalisation was also observed in other European countries and in the United States (Wolszczak-Derlacz, 2017). Thus, integration and cooperation within the international academic community is essential, and a new set of indicators is therefore being used to evaluate scientific effectiveness.

The concept of academic productivity is much narrower than that of scientific effectiveness, and it mainly focuses on publishing findings of the scientific output. It results in quantitative measures of scholars' research performance. Currently, the evaluation reform is undergoing and it will most probably result in profound changes related to the new Constitution for Science called Act 2.0. This law will probably expand the number of bibliometric indicators allowed for the evaluation of productivity by indicators provided by Elsevier Publishing, such as SNIP and CiteScore. However, at the time when this article is written, we do not know the exact guidelines that will apply, and that is why we use the indicators that have been obligatory until now. According to recommendations from the Polish Ministry of Science and Higher Education, special lists are published that rank and 
weigh scientific journals. Those lists ( $A, B$ and $C$ ) introduce publication points awarded on the basis of the inclusion in the Journal Citations Report database (list $A$ ), inclusion in Polish journals that have passed the evaluation process (list B) and inclusion in the ERIH database (list C). Other channels of publication, such as monographs and conference proceedings, are also awarded points. Further obligatory components have been selected and introduced; for example, scientists who apply for publicly funded grants have to provide the number of citations, including the individual Hirsch Index according to the Web of Science Core Collection database and the number of publications that have an Impact Factor and are indexed by the Journal Citations Report.

Kwiek's proposal $(2015 ; 2018)$ drew our attention to two further indicators of effectiveness: overall research engagement and internationalisation. Overall research engagement is primarily connected to the membership in national and international scientific boards and committees, acting as editors of peer-reviewed journals and writing reviews of scientific articles. Internationalisation is deemed to include working in national and international scientific teams, publishing in international journals and focusing on internationally oriented research, including comparative studies. Kwiek's findings showed that being affiliated to the top $10 \%$ of productive scientists in the STEM (science, technology, engineering and mathematics) subjects is strongly correlated with cooperating internationally, publishing in prestigious international journals, conducting research at the international level and having a research-oriented approach in terms of the academic lifecycle. It was also highlighted that serving as an editor in journals or for book boards has a significant impact on productivity (Kwiek, 2018). From the Polish perspective, the most productive scientists belong to research-oriented groups characterised by active involvement in international scientific teams, publishing in international scientific journals, serving as reviewers and editors and serving in national and international scientific boards (Kwiek, 2015).

\section{Academic Productivity: Evidence from Poland}

We wanted to explore how Polish academic productivity is recognized in Europe. For this purpose, we formulated the following questions: (1) how many documents were indexed in Web of Science, (2) how many times were Polish papers cited, and (3) how many Polish papers had authorship with international collaboration between 2015 and 2017? Finally, we compared the results to that of the United Kingdom, a leader in scientific effectiveness in Europe.

Data for this basic comparison came from the European Union countries, Norway, and Switzerland, and was provided by Web of Science and its InCites application (published by Clarivate Analytics). Datasets were built by running reports at the end of May 2018 based on a simple query using Web of Science Documents in InCites for the 2015-2017 period (Szuflita-Żurawska, Basinska, \& Leja, 2018).

Results showed that Poland ranks eighth among the European countries, with 119154 retrieved documents. Polish scientific documents were cited 305782 times. In absolute terms, the United Kingdom leads the scientific publication landscape in Europe with 594176 documents and 2129433 citations. In the same period, Polish academics published $20.05 \%$ as many papers. Polish universities employed 91603 academics compared to the United Kingdom's 206870 scientists, which makes $44.28 \%$. Interestingly, there were 390 public and non-public higher education organisations registered in Poland, whereas the United Kingdom is represented by 162 higher education institutions. Although the 
number of Polish scholars was close to half of the number of their British counterparts, the number of Polish documents amounted to one-fifth of the number of British ones.

Collaboration in publishing scientific papers is important to succeed across the research process. The percentage of international collaborations per country is defined as the number of publications with at least two different country affiliations among co-authors, divided by the total number of documents for that country. Our findings demonstrated that only $33.2 \%$ of papers by Polish authors indexed in Web of Science between 2015 and 2017 met the criterion for international co-authored publications. At the same time, over $50 \%$ of documents published by scientists from the United Kingdom had international collaboration. (Szuflita-Żurawska et al., 2018).

\section{Publication Practices within Scientific Disciplines}

Research results are typically disseminated through peer-reviewed scientific papers. The prestige of a journal is one of the crucial factors in terms of choosing a publishing channel by academics and many of them have decided to publish research in highly ranked international journals. However, publication practices vary within scientific disciplines. For example, in computer science, conference papers are more valued and more frequently cited than papers in scientific journals (Bar-llan, 2010; Goodrum et al., 2001). Anyway, due to factors such as the implementation of evaluation systems, publication practices in computer science have become more journal-oriented (Cavero, Vela, \& Cáceres, 2014).

In Poland, only a few scientific disciplines have scholarly communication practices in which the most important channel for disseminating research results is the publication of scientific articles in international journals. For other disciplines, such as the social sciences, this trend is rather a new phenomenon, and it is proving difficult to adopt, especially in the humanities (Kulczycki et al., 2018). Notable examples are popular monographs and book chapters that dominate publication output in the humanities. However, publication patterns have begun to transform in recent years. According to Kulczycki et al., since 2013, social science and humanities articles published and shared in Poland have increased from $20.71 \%$ to $48.08 \%$ of total publications. At the same time, book chapters have significantly decreased - from $65.04 \%$ of the total in 2011 to $46.28 \%$ in 2014, and monographs have dropped - from $14.25 \%$ of the total in 2011 to $5.64 \%$ in 2014.

\section{Barriers and Enhancers of Academic Productivity}

Some factors can facilitate and others can inhibit academic productivity and motivation for international collaboration. Existing studies have focused on institutional factors: barriers, such as teaching overload and funding levels, or facilitating factors, such as the size of an institution, its technical orientation, type of unit, geographic location, year of foundation or traditions (Bukowska \& Łopaciuk-Gonczaryk, 2013; Kwiek, 2015; Wolszczak-Derlacz, 2017; Wolszczak-Derlacz \& Parteka, 2011). Moreover, some institutional resources, both financial and structural, have a significant impact on the motivation to work. Previous studies have shown that employees expect that their remuneration will be fairly distributed and appropriate for the task (Landry et al., 2017; Olafsen et al., 2015; Siegrist, 1996). Furthermore, an engaging or transformational style of leadership contributes to work efficiency, enhances commitment to the organisation, as well as energises and brings together employees (Alimo-Metcalfe et al., 2008; Kim \& Beehr, 2017; Schaufeli, 2015). 
There has been an unfortunate neglect of the issues of academics' motivation, proactivity in sharing scientific knowledge, collaboration and building up of the academic community (Spreitzer et al., 2005). A number of studies regarding the importance of personal features - such as the "sacred spark" theory (Cole \& Cole, 1973) - have been conducted, but it would seem to be more beneficial in terms of organisation management in the higher education sector to motivate academics rather than to categorise them in terms of their personality predispositions. Thus, we aim to establish a sustainable process guided by an experienced management team that recognises the needs of scientists, helps employees to attain work motivation, and adjusts available resources to stimulate scientific effectiveness. To conclude, there is insufficient understanding in the higher education system of the relationship between motivation and scientific effectiveness.

\section{MATHERIAL AND METHODS}

The aim of the research is to conceptualise a model of work motivation in the management of universities striving for scientific excellence. The management of work motivation among scientists based on direct rewards and punishments, sometimes called "carrot and stick", has proved ineffective (Leja, 2015; Pink, 2009). The use of external instruments, mainly financial ones, is beneficial to routine work, but this comes at the expense of work that needs a creative and innovative environment (Cerasoli et al., 2014; Pink, 2009). Prior studies have mainly explored the efficacy of monetary rewards, while research on non-monetary rewards is relatively absent (Zaharie \& Seeber, 2018). Indeed, it is important to recognize how effective more intrinsic rewards are in increasing academics' productivity. This does not indicate, however, that motivation by means of external instruments is unnecessary but that a different approach to motivation is needed. Previous concepts of work motivation have tended to be dichotomous, contrasting, for example, extrinsic and intrinsic motivation (Gagne \& Deci, 2005). The modern approach must allow us to understand motivations as existing on a continuum with respect to preferred types of regulation (i.e., more extrinsic or more intrinsic), instead of treating externally regulated motives as opposed to the internal drive.

The most relevant forto our aim is the self-determination theory (Deci et al., 2017; Gagne \& Deci, 2005) that is applied to the work and organiszational domain. We used a narrative literature review (Baumeister \& Leary, 1997).

In the Google Scholar database we searched the terms "self-determination theory" and "work motivation". We found around 15000 documents. Therefore, we added the term "scientific productivity". As a result, we obtained 34 documents. We also used the term "academic motivation", however, the results in this case included too many documents about student and pupil motivation. In addition, we searched the terms "profile approach to self-determination" and "profiles of work motivation" due to the fact that we looked for combinations of different types of motivations. According to the initial criteria, articles in review needed to be available in English and published in peer-reviewed journals - they also had to describe work motivation on the self-determination continuum. Titles and abstracts that were retrieved were manually screened in order to verify our stipulations. Many studies reviewed did not meet the above-mentioned eligibility requirements and were excluded due to belonging to a non-work domain, being published in a language 
different than English, or being dissertation theses or duplicates. Finally, only 23 documents were included in the literature review and were used to build a model of work motivation in higher education settings.

\section{THEORY DEVELOPMENT: A CONCEPTUAL MODEL OF WORK MOTIVATION AMONG ACADEMICS}

\section{Self-Determination Theory in Work Organisations}

According to the self-determination theory in the work context (Deci et al., 2017), employees can be motivated in different ways that are not mutually exclusive. There are two major types of motivation, autonomous and controlled, and these may differ in their function and manner of regulation. Autonomous motivation is related to intrinsically regulated activities that facilitate the employee's authentic engagement, appreciation of meaningfulness and purpose, sense of personal agency and search for an internal drive towards job performance. Specific subtypes of autonomous motivation are intrinsic motivation and identified motivation, differing in the level of the internalisation of values, well-being involved. Intrinsic motivation encourages activity that is interesting in its own right and whose benefit is spontaneous satisfaction. Identified motivation is also regulated intrinsically, but its reward comes from cognitive fulfilment.

In contrast to autonomous motivation, controlled motivation is externally regulated. The employee expends effort in order to receive rewards and avoid punishments, with the result that short-term benefits, rather than growth and development, are achieved. Even if their job performance is good, employees whose motivation is more controlled are relatively poorly engaged in their professional roles. An example of controlled motivation is the extrinsic motivation, consisting of instrumental behaviours contingent on rewards and punishments, both material (e.g., money) and social (e.g., recognition and respect from others). A more mature form of controlled motivation is the introjected motivation, in the case of which employees take action as much in order to feel pleasure and pride as to avoid shame and guilt. The introjected motivation is considered to be enforced through its own internal system of reward and punishment.

In addition to autonomous and controlled motivation, there is also amotivation, a lack of motivation and unwillingness to work. Amotivated employees do not pursue the organisation's goals and, moreover, feel helpless and incompetent. The motivation continuum in the self-determination theory is presented in Figure 1.

\begin{tabular}{|l|c|c|c|c|c|}
\hline \multirow{2}{*}{$\begin{array}{l}\text { Quality of } \\
\text { behaviour }\end{array}$} & \multicolumn{2}{|l|}{ Non-self-determined } & \multicolumn{2}{|c|}{ Self-determined } \\
\hline \multirow{2}{*}{$\begin{array}{l}\text { Types of } \\
\text { motivation }\end{array}$} & Amotivation & \multicolumn{2}{|c|}{ Extrinsic motivation } & $\begin{array}{c}\text { Intrinsic } \\
\text { motivation }\end{array}$ \\
\cline { 2 - 6 } & & \multicolumn{2}{|c|}{ Controlled motivation } & Autonomous motivation \\
\hline $\begin{array}{l}\text { Regulator } \\
\text { styles }\end{array}$ & Non-regulation & $\begin{array}{c}\text { External } \\
\text { regulation }\end{array}$ & $\begin{array}{c}\text { Introjected } \\
\text { regulation }\end{array}$ & $\begin{array}{c}\text { Identified } \\
\text { regulation }\end{array}$ & $\begin{array}{c}\text { Intrinsic } \\
\text { regulation }\end{array}$ \\
\hline
\end{tabular}

Figure 1. The self-determination continuum showing types of motivation with regulatory styles Source: based on Deci et al. (2017), Gagne \& Deci (2005), Gagne et al. (2015). 
Employees who are autonomously motivated gain more benefits and incur fewer losses. They perform their tasks better and are more likely to feel happy, fulfilled and attached to the organisation (Gillet et al., 2017). Most importantly, they are more willing to share their knowledge. In contrast, controlled motivated employees experience more negative consequences in their jobs (Christensen et al., 2018; Klaeijsen, Vermeulen, \& Martens, 2017). They are more likely to feel exhausted and intend to leave or change their career pattern. Furthermore, they take little personal initiative and are reluctant to exchange knowledge, which means that they neither obtain knowledge from co-workers nor pass knowledge on (Cerasoli et al., 2014; Gagne et al., 2015; Howard et al., 2016).

Universities want to create conditions for professional thriving and to motivate their employees to achieve academic success. However, the management of motivation has to take account of the basic needs that fulfil employees, particularly the satisfaction of the needs for autonomy, mastery and purpose (Deci \& Ryan, 2000; Dahling \& Lauricella, 2016; Pink, 2009). Unfortunately, these motives and needs of employees have been examined separately in previous research (Deci et al., 2017). The need for autonomy reveals itself in people who would like to act independently and with personal agency, deciding which tasks to do, which methods to use, how fast to work and with whom to collaborate. Autonomy results in a greater sense of internal locus of control instead of being pushed or pulled by external factors. A drive for mastery is a need to be competent and to demonstrate ongoing development of professional skills and abilities. Mastery creates and strengthens self-efficacy in employees seeking new ideas and taking new challenges. Maximising purpose is connected with giving meaning to work, so that its goal is to broaden one's horizons and become part of something valuable and sustainable; purpose leads to a situation in which all the employee's actions contribute to benefits for the organisation (maximising profit) and for society (enhancing welfare and creating a sense of community).

Based on the self-determination theory, we propose a theoretical model of work motivation among academics. This model shows a system of assumptions, terms and relations between them, which allows to describe a fragment of reality. The aim is to capture the most important characteristics and relationships that enable it to be recognized. A graphical representation of the model is presented in Figure 2.

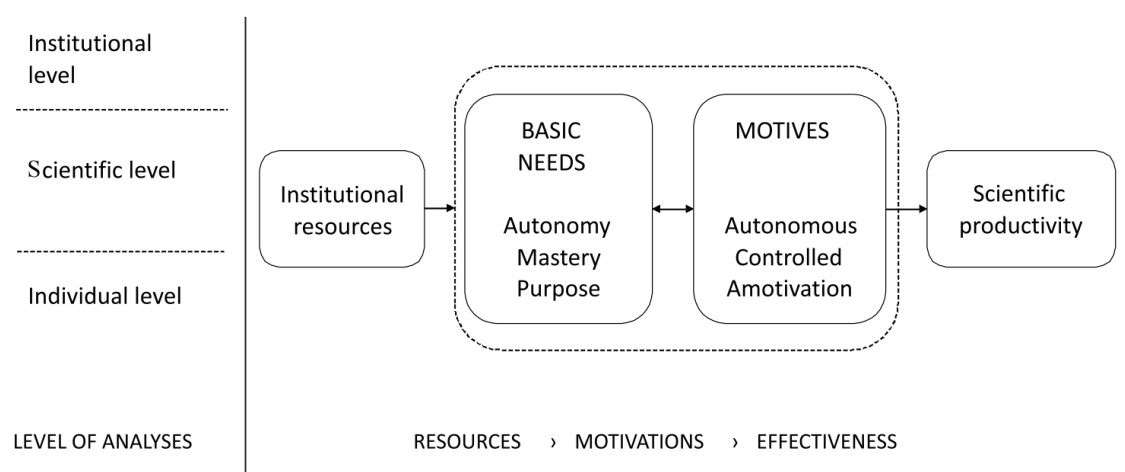

Figure 2. The model of work motivation among academics in a multilevel approach: indirect role of motivation in the relationship between institutional resources and scientific effectiveness at universities

Source: own elaboration. 
There are four theoretical propositions elaborated from our conceptual model.

First, the relationship between institutional resources (e.g., leadership style, organisational support, rewards) and scientific productivity can be mediated via the combination of psychological needs and different types of motivations (Christensen et al., 2018; Landry et al., 2017; Olafsen et al., 2015; Schaufeli, 2015).

Second, in heuristic work environments, the satisfaction of basic psychological needs, especially autonomy and mastery, facilitates autonomous motivation and this relationship can be reciprocal. As we mentioned above, few studies that connect needs with motives have been conducted (Deci et al., 2017; Klaeijsen et al., 2017; Van der Broeck et al., 2016).

Third, motivation should be understood as forming a continuum that stretches from more controlled to more autonomous regulation or involves a mixed profile of motivation (Gagne et al., 2015; Howard et al., 2016; Tremblay et al., 2009). Autonomous motivation was more correlated with the quality of performance, whereas extrinsic incentives were associated with the quantity of performance. In regard to performance, both autonomous and controlled motivation can be considered simultaneously (Cerasoli et al., 2014; Wollersheim et al., 2015). Moreover, findings suggest that several combinations of work motivations can, to varying degrees, successfully drive scientific productivity compared to the linear relation between motives and performance (Howard et al., 2016; Ryan \& Berbegal-Mirabent, 2016). Prior studies revealed four main profiles of motivation that were based on the combination of autonomous and controlled motivation. There were autonomously regulated, highly motivated, balanced motivation and amotivated profiles (Howard et al., 2016; Van der Burgt et al., 2018). Autonomously and highly motivated employees demonstrated higher work performance and incurred less personal costs of work compared to amotivated co-workers. Autonomous motivation can be more promising in promoting positive workplace outcomes due to the fact that it can mitigate a detrimental impact of controlled motivation.

Fourth, it is important to integrate knowledge from both perspectives, the institutional perspective of management through organisational resources and the employee perspective of satisfying individual needs and motives. Higher education institutions aiming to foster productivity among academics should adapt their incentive systems to the psychological needs and motives of academics in different stages of their career (Albert, Davia, \& Legazpe, 2018). It means that institutions could integrate more individual and institutional input and output for academic performance depending on specific scientific disciplines. Moreover, developing a more integrative incentive system to exploit synergies between different academic activities, e.g. publishing and teaching, and individual needs is a challenge for the management of universities (Blind et al., 2018). Based on the self-determination theory, the relational perspective provides new insights into understanding motivation in higher education settings. Universities want to seek to promote the emergence of psychological and relational conditions in order to enhance creativity and innovation (Teye et al., 2019).

In conclusion, the proposed model of work motivation among scientists is required to focus on positive activities to stimulate linking autonomous motivation with controlled motivation and to fulfil psychological needs for mastery (being competent), autonomy (being independent) and purpose (finding a meaning of work) in order to increase scientific effectiveness. 


\section{CONCLUSIONS}

\section{Implications and Recommendations}

The problem of academics' motivation is rooted in two paradigms, the management of paradoxes and Positive Organisational Scholarship. Recent changes in the landscape of scholarly communication have shown that motivation based on extrinsic instruments is inefficient and poorly matched to the goals of universities (Leja, 2015). So far, the effectiveness of academics has not been connected to proactive behaviour that promotes the building of scientific knowledge and disseminates it in the international space (Christensen et al., 2018). Furthermore, very few studies into motivation among academics have focused on varying degrees of scientific effectiveness between scientific disciplines that differ in their publication practices (Kulczycki et al., 2018).

\section{Contribution}

The proposed model of motivation in scientists has some theoretical and methodological innovations. First, the scientific elaboration of a new model of motivation in the management of universities can be empirically verified. Second, this model may integrate institutional and individual levels. Thus, managerial practices can be linked with academics' needs and preferred motives. Third, a multilevel examination of the motivation model between institutions, scientific disciplines, and academics will reveal the complexity of managing academics' motivations in relation to scientific effectiveness.

In conclusion, the self-determination continuum provides new insights into understanding of research motivation in higher education settings. The proposed model of motivation integrates different types of motives and psychological needs, as well as the individual, scientific and institutional perspectives. As a result, it will extend existing knowledge about the motivation of academics to strive for scientific excellence and will fill a gap in the areas of higher education and management science.

\section{Research Limitations}

Our study has some limitations regarding institutional resources and scientific disciplines. More attention should be given to differences among scientific disciplines that may be important for scientific productivity and motivations, as well as more accurate identification of relevant organisational resources, both financial and structural.

\section{Suggestion for Future Studies}

Future research can be focused on the empirical verification of the motivation model in higher education institutions. The examination of the model of motivation in the management of universities can integrate the institutional and the individual lenses. Moreover, scientific fields can be taken into consideration. The implementation of the self-determination theory allows to observe the complexity of managing scholars' motivations in relation to scientific effectiveness, as well as the differences between various institutions, scientific fields and individuals. 


\section{REFERENCES}

Albert, C., Davia, M.A., \& Legazpe, N. (2018). Job satisfaction amongst academics: the role of research productivity. Studies in Higher Education, 43(8), 1362-1377.

Alimo-Metcalfe, B., Alban-Metcalfe, J., Bradley, M., Mariathasan, J., \& Samele, C. (2008). The impact of engaging leadership on performance, attitudes to work and wellbeing at work: A longitudinal study. Journal of Health Organization and Management, 22(6), 586-598.

Bar-llan, J. (2010). Web of Science with the Conference Proceedings Citation Indexes: The case of computer science. Scientometrics, 83(3), 809-824. https://doi.org/10.1007/s11192-009-0145-4.

Baumeister, R.F., \& Leary, M.R. (1997). Writing narrative literature reviews. Review of General Psychology, 1(3), 311-320.

Blind, K., Pohlisch, J., \& Zi, A. (2018). Publishing, patenting, and standardization: Motives and barriers of scientists. Research Policy, 47(7), 1185-1197.

Bukowska, G., \& Łopaciuk-Gonczaryk, B. (2013). Determinanty sukcesów publikacyjnych naukowców. Nauka, (3), 59-86.

Cameron, K., Dutton, J., \& Quinn, R.E. (Eds.) (2003). Positive organizational scholarship: Foundations of a new discipline. San Francisco, California: Berrett-Koehler Publishers, Inc.

Cameron, K.S., \& Spreitzer, G.M. (Eds.), (2011). The Oxford handbook of positive organizational scholarship. Oxford: Oxford University Press.

Cavero, J.M., Vela, B., \& Cáceres, P. (2014). Computer science research: More production, less productivity. Scientometrics, 98(3), 2103-2111. https://doi.org/10.1007/s11192-013-1178-2

Cerasoli, C.P., Nicklin, J.M., \& Ford, M.T. (2014). Intrinsic motivation and extrinsic incentives jointly predict performance: A 40-year meta-analysis. Psychological Bulletin, 140(4), 980-1009.

Christensen, M., Dyrstad, J.M., \& Innstrand, S.T. (2018). Academic work engagement, resources and productivity: empirical evidence with policy implications. Studies in Higher Education, 1-14. https://doi.org/10.1080/03075079.2018.1517304

Carivate Analytics. (2017). InCities Indicators Handbook.

Cohen, M. (1998). The performance paradox. Academy of Management Executive, 12(3), 30-40.

Cole, J., \& Cole, S. (1973). Social Stratification in Science. Chicago: The University of Chicago Press.

Dahling, J.J., \& Lauricella, T.K. (2016). Linking job design to subjective career success: a test of selfdetermination theory. Journal of Career Assessment, 25(3), 371-388.

Deci, E.L., Olafsen, A.H., \& Ryan, R.M. (2017). Self-determination theory in work organizations: the state of a science. Annual Review of Organizational Psychology and Organizational Behavior, 4, 19-43.

Deci, E.L., \& Ryan, R.M. (2000). The "what" and /"why" of goal pursuits: Human needs and the selfdetermination of behavior. Psychological Inquiry, 11(4), 227-268.

Gagné, M., \& Deci, E.L. (2005). Self-determination theory and work motivation. Journal of Organizational Behavior, 26(4), 331-362.

Gagné, M., Forest, J., Vansteenkiste, M., Crevier-Braud, L., Van den Broeck, A., Aspeli, A.K., ... \& Halvari, H. (2015). The Multidimensional Work Motivation Scale: Validation evidence in seven languages and nine countries. European Journal of Work and Organizational Psychology, 24(2), 178-196.

Gillet, N., Becker, C., Lafrenière, M.A., Huart, I., \& Fouquereau, E. (2017). Organizational support, job resources, soldiers' motivational profiles, work engagement, and affect. Military Psychology, 29(5), 418-433. 
Goodrum, A.A., McCain, K.W., Lawrence, S., \& Lee Giles, C. (2001). Scholarly publishing in the Internet age: a citation analysis of computer science literature. Information Processing \& Management, 37(5), 661-675. https://doi.org/10.1016/S0306-4573(00)00047-9

Howard, J., Gagne, M., Morin, A.J., \& Van den Broeck, A. (2016). Motivation profiles at work: A selfdetermination theory approach. Journal of Vocational Behavior, 95, 74-89.

Kim, M., \& Beehr, T.A. (2017). Can Empowering Leaders Affect Subordinates' Well-Being and Careers Because They Encourage Subordinates' Job Crafting Behaviors?. Journal of Leadership \& Organizational Studies,1-13. https://doi.org/10.1177/1548051817727702

Klaeijsen, A., Vermeulen, M., \& Martens, R. (2017). Teachers' Innovative Behaviour: The Importance of Basic Psychological Need Satisfaction, Intrinsic Motivation, and Occupational Self-Efficacy. Scandinavian Journal of Educational Research, 62(5), 1-14.

Krupski, R., Niemczyk, J., \& Stańczyk-Hugiet, E. (2009). Koncepcje strategii organizacji. Warszawa: Polskie Wydawnictwo Ekonomiczne.

Kulczycki, E., Engels, T.C.E., Pölönen, J. Bruun, K., Dušková, M., Guns, R., Nowotniak, R., Petr, M., Sivertsen, G., Starčič, A.I., \& Zuccalaet A. (2018). Publication patterns in the social sciences and humanities: evidence from eight European countries. Scientometrics, 116(1), 463-486. https://doi.org/10.1007/s11192-018-2711-0

Kwiek, M. (2015). Uniwersytet $w$ dobie przemian: instytucje i kadra akademicka w warunkach rosnqcej konkurencji. Warszawa: PWN.

Kwiek, M. (2018). High research productivity in vertically undifferentiated higher education systems: Who are the top performers? Scientometrics, 115(1), 415-462.

Landry, A.T., Gagné, M., Forest, J., Guerrero, S., Séguin, M., \& Papachristopoulos, K. (2017). The relation between financial incentives, motivation, and performance: An integrative SDT-based investigation. Journal of Personnel Psychology, 16(2), 61.

Leja, K. (2013). Zarzqdzanie uczelniq. Koncepcje i współczesne wyzwania. Warszawa: Oficyna Wolters Kluwer.

Leja, K. (2015). Positive management of the university. Journal of Positive Management, 6(2), 59-71.

Lewis, M. (2000). Exploring paradoxes: Toward a more comprehensive guide. Academy of Management Review, 25(4), 770-776.

Olafsen, A.H., Halvari, H., Forest, J., \& Deci, E.L. (2015). Show them the money? The role of pay, managerial need support, and justice in a self-determination theory model of intrinsic work motivation. Scandinavian Journal of Psychology, 56(4), 447-457.

Pink, D.H. (2009). Drive: The surprising truth about what motivates us. New York: Penguin.

Ryan, J.C., \& Berbegal-Mirabent, J. (2016). Motivational recipes and research performance: A fuzzy set analysis of the motivational profile of high performing research scientists. Journal of Business Research, 69(11), 5299-5304.

Schaufeli, W.B. (2015). Engaging leadership in the job demands-resources model. Career Development International, 20(5), 446-463.

Scott, J.C. (2006). The Mission of the University: Medieval to Postmodern Transformations. Journal of Higher Education, 77(1), 1-39. https://doi.org/10.1353/jhe.2006.0007

Siegrist, J. (1996). Adverse health effects of high-effort/low-reward conditions. Journal of Occupational Health Psychology, 1(1), 27-41.

Smith, W.K., \& Lewis, M.W. (2011). Toward a theory of paradox: a dynamic equilibrium model of organizing. Academy of Management Review, 36(2), 381-403. 
Spreitzer, G., Sutcliffe, K., Dutton, J., Sonenshein, S., \& Grant, A.M. (2005). A socially embedded model of thriving at work. Organization Science, 16(5), 537-549.

Szuflita-Żurawska, M., Basińska, B.A., \& Leja, K. (2018). New model of motivation among academics: data of polish scientific productivity. Unpublished manuscript. Gdańsk: Faculty of Management and Economics, Gdansk University of Technology

Tabatoni P. (2002). Strategic management, a tool of leadership - concepts and paradoxes. In P. Tabatoni, J. Davies, \& A. Barblan (Eds.), Strategic management and universities institutional development. EUA-European University Association.

Teye, E.T., Abosi, B.A., Tetteh, A.N., Ntim, S.Y., Teye, A., Aseidua-Ayeh, O.L., \& Dubi, S.A. (2019). Linking motivation and alliance to perceived ambidexterity outcomes at the individual level in academia. Journal of Applied Research in Higher Education. https://doi.org/10.1108/JARHE-10-2018-0205

Tremblay, M.A., Blanchard, C.M., Taylor, S., Pelletier, L.G., \& Villeneuve, M. (2009). Work Extrinsic and Intrinsic Motivation Scale: Its value for organizational psychology research. Canadian Journal of Behavioural Science/Revue Canadienne des Sciences du Comportement, 41(4), 213-226.

Van den Broeck, A., Ferris, D.L., Chang, C.H., \& Rosen, C.C. (2016). A review of self-determination theory's basic psychological needs at work. Journal of Management, 42(5), 1195-1229.

Van der Burgt, S.M.E., Kusurkar, R.A., Wilschut, J.A., Tjin A Tsoi, S.L.M.M., Croise, G., \& Peerdeman, S.M. (2018). Motivational Profiles and Motivation for Lifelong Learning of Medical Specialists. The Journal of Continuing Education in the Health Professions, 38(3), 171-178. https://doi.org/10.1097/CEH.0000000000000205.

Wolszczak-Derlacz, J. (2017). An evaluation and explanation of (in) efficiency in higher education institutions in Europe and the US with the application of two-stage semi-parametric DEA. Research Policy, 46(9), 1595-1605.

Wolszczak-Derlacz, J., \& Parteka, A. (2011). Efficiency of European public higher education institutions: a two-stage multicountry approach. Scientometrics, 89(3), 887-917.

Wollersheim, J., Lenz, A., Welpe, I.M., \& Spörrle, M. (2015). Me, myself, and my university: a multilevel analysis of individual and institutional determinants of academic performance. Journal of Business Economics, 85(3), 263-291.

Zaharie, M.A., \& Seeber, M. (2018). Are non-monetary rewards effective in attracting peer reviewers? A natural experiment. Scientometrics, 117(3), 1587-1609.

The copyediting and proofreading of articles in English is financed in the framework and Higher Education of contract No. 913/P-DUN/2019 by the Ministry of Science and Higher Education Republicoffoland $\quad$ of the Republic of Poland committed to activities aimed at science promotion. 


\section{Authors}

The contribution share of co-authors can be expressed as Beata A. Basińska (50\%), Krzysztof Leja (15\%) and Magdalena Szuflita-Żurawska (35\%).

\section{Beata A. Basińska}

Master of Social Science in Psychology (University of Gdansk, Poland); PhD in Psychology (University of Gdansk, Poland); Doctor habilitatus in Psychology (SWPS University of Social Sciences and Humanities, Warsaw, Poland); Associate Professor of Gdansk University of Technology (Poland). Her research interests include positive management and organisational psychology.

Correspondence to: Beata A. Basińska, PhD, Gdansk University of Technology, Faculty of Management and Economics, 11/12 Narutowicza St., 80-233 Gdansk, Poland, e-mail: Beata.Basinska@pg.edu.pl

ORCID (1) http://orcid.org/0000-0002-6532-7093

\section{Krzysztof Leja}

Master of Applied Physics (Gdansk University of Technology, Poland - GUT), PhD in economics (GUT), habilitation in management (University of Economics in Katowice, Poland), associate professor and vice-dean for research at the Faculty of Management and Economics, GUT. His fields of interest include research HEls and policy studies. He is an expert of Polish Rectors Foundation and Ministry of Science and Higher Education and in "European Tertiary Education Register" (ETER) 2013-2020.

Correspondence to: Krzysztof Leja, PhD, Gdansk University of Technology, Faculty of Management and Economics, 11/12 Narutowicza St., 80-233 Gdansk, Poland, e-mail: Krzysztof.Leja@zie.pg.edu.pl

ORCID (i) http://orcid.org/0000-0001-5594-2204

\section{Magdalena Szuflita-Żurawska}

Master of Science in Digital Library Management and Information Science (University of Boras, Sweden). Her research interests include scholarly communication and positive management of university.

Correspondence to: Magdalena Szuflita-Żurawska, Gdansk University of Technology Library and Faculty of Management and Economics, Narutowicza 11/12 St., 80-233 Gdansk, Poland, e-mail: Magdalena.Szuflita@pg.edu.pl

ORCID (1) http://orcid.org/0000-0002-1490-8234

\section{Acknowledgements and Financial Disclosure}

The article came into being within the project no. DEC-2017/27/B/HS4/01033 entitled 'Positive Management of Technical Universities: A New Model of Work Motivation' financed by the National Science Centre, Poland in the years 2018-2021, principle investigator Beata A. Basińska.

\section{Copyright and License}

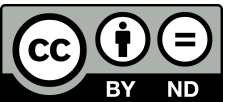

This article is published under the terms of the Creative Commons Attribution - NoDerivs (CC BY-ND 4.0) License http://creativecommons.org/licenses/by-nd/4.0/ 